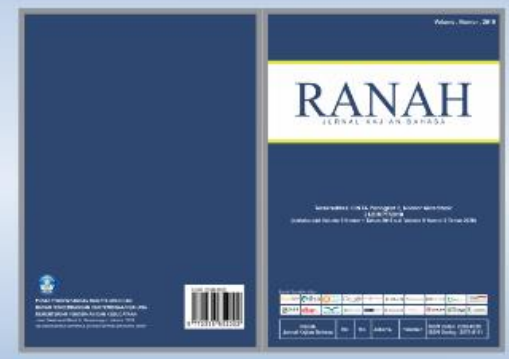

Ranah: Jurnal Kajian Bahasa

ojs.badanbahasa.kemdikbud.go.id/jurnal/index.php/jurnal_ranah

p-ISSN: $2338-8528$

e-ISSN: $2579-8111$

\title{
MAKNA KATA DALAM BAHASA INDONESIA \\ (SALAH KAPRAH DAN UPAYA PERBAIKANNYA)
}

The Meaning of Words in Indonesian Language

(On Misleading Words and the Corrections Efforts)

\author{
Syahru Ramadan ${ }^{a}$ dan Yeti Mulyatib \\ anstitut Agama Islam Negeri Bone \\ bUniversitas Pendidikan Indonesia \\ syahru.ramadan.unm@upi.edu
}

Naskah Diterima Tanggal 25 November 2018-Direvisi Akhir Tanggal 9 April 2020_Disetujui Tanggal 22 Mei 2020 doi: https://doi.org/10.26499/rnh/v9i1.1036

\begin{abstract}
Abstrak
Seringkali dalam memahami atau memaknai kata dalam bahasa Indonesia terjadi salah kaprah atau kesalahan yang dianggap sebagai kebenaran sehingga hal itu acap kali membuat pemahaman terhadap bahasa Indonesia keliru. Penelitian ini hadir untuk mendeskripsikan persepsi pengguna bahasa Indonesia mengenai kata-kata yang sering disalahkaprahkan maknanya dan upaya memperbaikinya. Penelitian ini berwujud deskriptif kualitatif dengan peneliti dan angket sebagai instrumen utama. Data disajikan dengan metode simak dengan teknik simak bebas cakap dan catat. Penelitian ini memberikan hasil bahwa (1) dari 10 kata yang dimaknai oleh pengguna bahasa Indonesia, hanya 3 kata yang dimaknai sesuai dengan Kamus Besar Bahasa Indonesia (KBBI, 2013) dan 7 kata lainnya dimaknai salah kaprah. Kata-kata yang dimaknai sesuai dengan KBBI (2013) adalah absen, absensi, dan kosong. Kata-kata yang dimaknai keliru adalah acuh, bergeming, nuansa, seronok, carut-marut, notulen, dan rempong. Beberapa faktor yang menjadi penyebab pemaknaan tersebut adalah melihat di media massa, sering mendengar dari orang lain (masyarakat), menjadi kebiasaan sehari-hari, dan melihat makna dalam kamus. (2) Upaya memperbaiki pemaknaan itu dengan cara mewajibkan media massa untuk menggunakan makna yang sesuai dengan KBBI (2013), meningkatkan kualitas bahasa Indonesia para pendidik, menumbuhkan sikap positif terhadap bahasa Indonesia, dan menetapkan aturan yang mengikat bagi pengguna bahasa Indonesia.
\end{abstract}

Kata-Kata Kunci: salah kaprah, pemaknaan kata, pengguna bahasa Indonesia

\begin{abstract}
Often in understanding or interpreting words in the Indonesian language mistaken or mistaken things are considered as truth so that it often makes the understanding of the Indonesian language wrong. This research is here to describe the perception of Indonesian language users about words that are often misunderstood and their efforts to improve them. This research is in the form of descriptive qualitative research and questionnaire as the main instrument. Data is presented by the method of referring to the technique of listening and note-free. This research gives the result that (1) out of 10 words that are interpreted by Indonesian users, only 3 words are interpreted following Kamus Besar Bahasa Indonesia (KBBI, 2013) and 7 other words are interpreted incorrectly. The words that are interpreted according to KBBI (2013) are absen, absensi, and kosong. Words that are interpreted incorrectly are acuh, bergeming, nuansa, seronok, carut-marut, notulen, and rempong. Some of the factors that cause the meaning are seeing in the mass media, often hearing from other people (the public), becoming a daily habit, and seeing the meaning in the dictionary. (2) Efforts to improve the interpretation by requiring the mass media to use the meaning appropriate to the KBBI (2013), improve the quality of the Indonesian language of educators, foster a positive attitude towards the Indonesian language, and establish binding rules for Indonesian language users.
\end{abstract}

Keywords: misguided, words meaning, Indonesian user community

How to Cite: Ramadan, Syahru dan Yeti Mulyati. (2020). Makna Kata dalam Bahasa Indonesia (Salah Kaprah dan Upaya Perbaikannya). Ranah: Jurnal Kajian Bahasa, 9(1), 90-105. doi: https://doi.org/10.26499/rnh/v9i1.1036 


\section{PENDAHULUAN}

Peradaban manusia telah berkembang pesat. Hal itu dapat dilihat pada perkembangan peradaban di abad XXI yang memasuki budaya maya (cybercultures). Peradaban ini ditandai dengan perkembangan pesat dalam bidang komunikasi dan teknologi informasi. Peradaban ini memberi dampak pada seluruh bidang kehidupan manusia, baik politik, pendidikan, ekonomi, maupun bahasa. Bahasa itu beraneka ragam. Salah satunya adalah bahasa Indonesia-bahasa yang menjadi ciri khas negara Indonesia yang membedakannya dengan negara-negara lain.

Berkaitan dengan bahasa Indonesia, terdapat hal yang menarik, yaitu penggunaannya yang saat ini mulai terabaikan, dalam arti penghargaan terhadap bahasa Indonesia mulai menurun. Masyarakat Indonesia perlahan lebih memilih dan bangga berbahasa asing, khususnya berbahasa Inggris. Dalam penelitian Susanti (2015), Rahayu (2015), Marsudi \& Zahrok (2015) ditemukan hasil bahwa di ruang publik, penggunaan bahasa Inggris sering dijumpai, khususnya di fasilitas umum dan media massa. Beberapa lembaga yang menggunakan bentuk tulisan dengan dua bahasa sekaligus juga lebih mendahulukan penggunaan bahasa Inggris daripada bahasa Indonesia. Padahal, dalam UU No. 24 Tahun 2009 telah dijelaskan bahwa bahasa Indonesia wajib digunakan terlebih dahulu dan dapat disusul oleh bahasa asing sebagai pelengkapnya.

Selain itu, fenomena penggunaan bahasa gaul turut serta membuat penghargaan terhadap bahasa Indonesia menurun. Sari (2015) dalam penelitiannya mengungkapkan bahwa bahasa gaul dapat memberi beberapa dampak kepada bahasa Indonesia, yaitu (a) membuat eksistensi bahasa Indonesia terpinggirkan; (b) membuat derajat bahasa Indonesia menurun; dan (c) dapat menyebabkan bahasa Indonesia punah.

Dengan berkaca pada fenomena itu, sudah selayaknya eksistensi bahasa Indonesia tetap dijaga dan dilestarikan. Akan tetapi, hal itu akan sulit dilakukan. Sartini (2014: 208) dalam penelitiannya mengungkapkan bahwa saat ini bahasa Indonesia menjadi bahasa yang kacau. Kekacauan itu terjadi pada tataran struktur, kosa kata, dan semantik. Diungkapkan bahwa terdapat beberapa penyebab kekacauan itu, antara lain (a) penggunaan bahasa Inggris yang berlebihan dan salah kaprah; (b) pelanggaran kaidah-kaidah bahasa Indonesia, baik di tempat-tempat umum maupun di media massa; (c) masuknya struktur kalimat bahasa daerah yang tidak sesuai dengan kaidah bahasa Indonesia yang benar; (d) penggunaan akronim secara sewenang-wenang; (e) munculnya bahasa gaul dengan 
berbagai proses pembentukannya; dan (f) munculnya bahasa birokrasi yang singkat dengan jargon-jargon khusus.

Semua penyebab itu semakin memudarkan pemahaman masyarakat terhadap kaidah bahasa Indonesia yang baik dan benar. Bahkan, masyarakat sering memunculkan dua bentuk kata yang saling berkompetisi dalam penggunaan bahasa Indonesia sehari-hari (Setyadi, 2015: 74). Misalnya, pada kata mengubah dan merubah.

Selain itu, masyarakat Indonesia sering memaknai kata dengan tidak bersumber pada KBBI. Contohnya pada kata acuh. Masyarakat sering mengartikan kata acuh dengan makna tidak peduli. Padahal, makna sebenarnya dalam KBBI (2013) adalah peduli. Kesalahan itu jika diterima, tentu akan berujung pada salah kaprah atau kesalahan yang telah dianggap sebagai kebenaran. Kesalahan tersebut sering dijumpai pada media massa.

Berdasarkan penelitian yang dilakukan oleh Ramadan (2017), ditemukan bahwa media massa melakukan penyalahkaprahan makna pada beberapa kata. Penyalahkaprahan makna tersebut berupa pertukaran makna, seperti kata acuh yang dimaknai tidak pedulimakna aslinya peduli dan absen yang dimaknai hadir-makna aslinya tidak hadir. Selain itu, terdapat juga pemaknaan yang tidak berhubungan dengan makna aslinya, seperti kata carut-marut yang dimaknai tidak keruan-makna aslinya perkataan kasar atau goresan bekas luka dan nuansa yang dimaknai suasana-makna aslinya variasi.

Jika masalah-masalah itu tidak diperbaiki, keadaan bahasa Indonesia akan semakin kacau. Hal itu berdampak pula pada eksistensi bahasa Indonesia yang akan menghilang di masa depan diakibatkan oleh penggunaan bahasa Indonesia yang seenaknya dan tanpa memperhatikan kaidah-kidah kebahasaan.

Berangkat dari permasalahan tersebut, peneliti membuat penelitian yang memotret fenomena pemaknaan kata. Penelitian ini bertujuan untuk mendeskripsikan persepsi pengguna bahasa Indonesia dalam memaknai kata-kata yang sering disalahkaprahkan maknanya. Penelitian ini merupakan kelanjutan dari penelitian Ramadan (2017). Jika Ramadan meneliti kata-kata yang disalahkaprahkan maknanya oleh media massa, maka penelitian ini memotret persepsi pengguna bahasa Indonesia. Penelitian ini juga dikhususkan untuk memotret persepsi pengguna bahasa Indonesia dari kalangan berpendidikan minimal SMA. Selain itu, upaya-upaya untuk mengatasi penyalahkaprahan tersebut juga akan dipaparkan dalam penelitian ini. Hal itu dilakukan untuk mengembalikan eksistensi bahasa Indonesia yang baik dan benar. 


\section{LANDASAN TEORI}

Teori semantik merupakan teori yang digunakan dalam penelitian ini. Dalam teori tersebut, terdapat beberapa subbagian. Dalam penelitian ini digunakan subbagian perubahan dan pergeseran makna. Perubahan makna merupakan gejala makna awal mengalami perubahan. Sementara itu, pergeseran makna adalah gejala penyempitan, perluasan, penyinestesiaan, pengonotasian, dan pengasosiasian sebuah makna kata yang masih hidup dalam satu medan makna. Dalam pergeseran, makna rujukan awal tidak berubah atau diganti, tetapi mengalami perluasan atau penyempitan rujukan (Parera, 2004). Dilihat dari hal itu, antara perubahan dan pergeseran makna terdapat keterkaitan yang sangat erat dan tidak dapat dipisahkan. Hal itu dikarenakan antara perubahan dan pergeseran makna terdapat hubungan sebab-akibat. Perubahan makna dapat terjadi diakibatkan oleh pergeseran makna.

Perubahan dan pergeseran makna memiliki beberapa faktor penyebab. Pertama, bahasa diwariskan dari generasi dahulu ke generasi selanjutnya dengan cara langsung atau tidak langsung. Misalnya, seorang anak belajar bahasa dalam bentuk yang baru-dalam artian tanggapan seorang anak terhadap makna didasarkan pada konteks pemakaiannya. Anak tersebut sering mendengarkan atau membaca kata acuh dengan makna tidak peduli. Anak tersebut sampai pada simpulan bahwa kata acuh memang bermakna tidak peduli, bukan peduli. Pemahaman tersebut jika tidak diperbaiki, tentu berujung pada kesalahan dan hal itulah yang menjadi penyebab awal pergeseran makna.

Kedua, ketidakpastian atau kekaburan makna. Makna kata yang tidak akrab di telinga pengguna bahasa dapat menjadi sumber kekaburan makna yang berakibat pada terjadinya pergeseran makna.

Ketiga, kehilangan motivasi. Sepanjang sebuah kata tetap dengan kuat berpegang pada akar makna awal dan pada medan makna yang sama, pergeseran makna itu tidak terjadi. Namun sebaliknya, jika kata kehilangan motivasi makna awal, makna jadi berkembang dan tidak terkendali.

Keempat, salah kaprah adalah faktor yang menyebabkan perubahan dan pergeseran makna. Salah kaprah merupakan kesalahan yang terjadi secara terus-menerus dan telah menjadi kebiasaan tanpa usaha memperbaikinya. Kesalahan tersebut akhirnya diterima sebagai kebenaran. Salah kaprah ini sering ditemukan dalam bidang bahasa yang menjadikan makna kata mengalami perluasan atau penyempitan (Ullman dalam Sumarsono, 2012: 251). 
Telah disinggung sebelumnya bahwa salah satu faktor penyebab terjadinya perubahan dan pergeseran makna adalah salah kaprah. Salah kaprah adalah kesalahan yang terjadi karena kebiasaan dengan sesuatu yang salah tersebut dan dibiarkan terus berjalan tanpa usaha memperbaikinya. Salah kaprah ini sering ditemukan dalam bidang bahasa yang menjadikan makna kata mengalami perluasan atau penyempitan (Ullman dalam Sumarsono, 2012: 251). Sejalan dengan hal itu, Rosidi (2010: 199) mengungkapkan bahwa salah kaprah adalah kesalahan yang telah diterima oleh masyarakat-dalam hal ini kesalahan tersebut telah banyak dilakukan oleh masyarakat dan telah dianggap sebagai kebenaran.

Berdasarkan dari pandangan tersebut, salah kaprah adalah salah satu bentuk kesalahan yang terus berulang, tanpa upaya perbaikan, dan telah diterima oleh masyarakat banyak sebagai suatu kebenaran. Salah kaprah sering terjadi pada pemaknaan kata. Jika hal itu dibiarkan, tentu berujung pada ketidakkonsistenan penggunaan kaidah atau aturan kebahasaan dalam berbahasa Indonesia. Ketidakkonsistenan itu pula menyebabkan pengguna bahasa secara seenaknya tidak menghargai penggunaan bahasa Indonesia yang baik dan benar. Jangka panjang dari hal itu akan berakibat pada bahasa Indonesia semakin kacau.

\section{METODE PENELITIAN}

Berdasarkan judul penelitian ini, yakni "Makna Kata dalam Bahasa Indonesia (Salah Kaprah dan Upaya Perbaikannya)", penelitian ini tergolong dalam jenis penelitian deskriptif kualitatif yang bertujuan mendeskripsikan persepsi pengguna bahasa Indonesia dalam memaknai kata-kata bahasa Indonesia.

Kata-kata dan kalimat merupakan data dalam penelitian ini. Angka digunakan hanya untuk mendukung pendeskripsian hasil penelitian. Penelitian ini menggunakan data berupa persepsi dari tujuh puluh orang pengguna bahasa Indonesia-minimal berpendidikan SMA. Pemilihan responden tersebut didasarkan atas kebutuhan penelitian yang ingin memotret persepsi pengguna bahasa Indonesia, khususnya yang berpendidikan menengah ke atas. Sumber datanya adalah masyarakat pengguna bahasa Indonesia. Penelitian ini tidak membuat standar jumlah responden, tetapi melihat sejauh mana analisis data menjadi jenuh. Berikut ini disajikan tabel data responden. 
Tabel 1

Data Responden

\begin{tabular}{|c|c|c|}
\hline \multicolumn{2}{|c|}{ Responden } & Jumlah \\
\hline \multirow{2}{*}{ Jenis Kelamin } & Laki-Laki & 33 \\
\hline & Perempuan & 37 \\
\hline \multirow{3}{*}{ Pendidikan } & SMA & 12 \\
\hline & S1 & 48 \\
\hline & $\mathrm{S} 2$ & 10 \\
\hline \multirow{12}{*}{ Pekerjaan } & Wiraswasta & 8 \\
\hline & $E O$ & 1 \\
\hline & Frelancer & 1 \\
\hline & Guru & 7 \\
\hline & Ibu Rumah Tangga & 5 \\
\hline & Karyawan Swasta & 6 \\
\hline & Mahasiswa & 32 \\
\hline & PNS & 3 \\
\hline & Pelajar SMA & 4 \\
\hline & Petani Kopi & 1 \\
\hline & Pustakawan & 1 \\
\hline & Satpam & 1 \\
\hline
\end{tabular}

Kemudian, pemilihan sepuluh kata didasarkan pada studi pendahuluan terhadap beberapa media massa, baik cetak maupun elektronik. Dari studi pendahuluan tersebut diperoleh sepuluh kata yang sering disalahkaprahkan maknanya.

Peneliti merupakan instrumen utama dalam penelitian ini. Peneliti bertugas sebagai pengumpul dan penganalisis data. Peneliti memproses dan mengklarifikasi data secepat dan seakurat mungkin (Moleong, 2005: 171). Penelitian ini menggunakan alat bantu berupa angket yang berisi kata-kata yang sering disalahkaprahkan maknanya. Angket tersebut terdiri atas dua bagian. Bagian pertama berisi daftar kata beserta dua kalimat dengan masing-masing konteks yang mendukung makna leksikal kata atau makna yang sesuai dalam kamus (Jeniarti, 2019: 80). Untuk masing-masing kata disediakan dua kalimat dan responden diharuskan memilih salah satu kalimat tersebut yang dianggap benar. Kemudian, bagian kedua berisi alasan responden dalam memaknai kata-kata di bagian pertama. Angket tersebut sebelum digunakan terlebih dahulu divalidasi oleh ahli kebahasaan dan ahli wacana.

Teknik simak bebas cakap dan catat digunakan dalam penelitian ini. Teknik tersebut digunakan karena merupakan penyimakan penggunaan bahasa. Istilah menyimak tidak hanya berkaitan dengan penggunaan bahasa lisan, tetapi juga bahasa tulisan (Mahsun, 2005: 92).

Kemudian, untuk menganalisis data, dalam penelitian ini digunakan model analisis Miles dan Huberman (1992) yang terdiri atas tiga tahap, yaitu reduksi data (memilah dan memilih unsur yang diteliti berupa persepsi pengguna bahasa Indonesia dalam memaknai 
kata), verifikasi data (menganalisis persepsi dan membuat upaya-upaya perbaikan salah kaprah pemaknaan kata), dan penarikan simpulan.

Kamus Besar Bahasa Indonesia disingkat KBBI (2013), baik daring maupun luring, digunakan sebagai sumber acuan utama pemaknaan kata dalam penelitian ini. Selanjutnya, peneliti melakukan pemeriksaan dengan serius membaca, mengecek, dan mengintensifkan analisis data untuk memperkuat keabsahan data dalam penelitian ini.

\section{PEMBAHASAN}

Pembahasan hasil penelitian ini disesuaikan dengan tujuan penelitian, yaitu (1) mendeskripsikan persepsi masyarakat pengguna bahasa Indonesia dalam memaknai kata-kata yang sering disalahkaprahkan; dan (2) mendeskripsikan upaya memperbaiki kesalahan pemaknaan tersebut.

\section{Persepsi Masyarakat Pengguna Bahasa dalam Memaknai Kata dalam Bahasa Indonesia}

Dalam penelitian ini dikumpulkan persepsi dari tujuh puluh responden pengguna bahasa Indonesia. Kata-kata yang dimaknai oleh mereka terdiri atas acuh, bergeming, absen, absensi, nuansa, kosong, seronok, carut-marut, notulen, dan rempong. Persepsi para pengguna bahasa Indonesia tersebut dapat dilihat pada tabel berikut.

Tabel 2

Persepsi Pengguna Bahasa Indonesia

\begin{tabular}{lcc}
\hline \multirow{2}{*}{ Kata } & \multicolumn{2}{c}{ Frekuensi } \\
\cline { 2 - 3 } & $\begin{array}{c}\text { Benar } \\
\text { (Pemaknaan Sesuai KBBI) }\end{array}$ & $\begin{array}{c}\text { Salah } \\
\text { (Pemaknaan Tidak Sesuai KBBI) }\end{array}$ \\
\hline acuh & 31 & 39 \\
\hline bergeming & 17 & 53 \\
\hline absen & 55 & 15 \\
\hline absensi & 43 & 27 \\
\hline nuansa & 31 & 39 \\
\hline kosong & 50 & 20 \\
\hline seronok & 27 & 43 \\
\hline carut-marut & 18 & 52 \\
\hline notulen & 23 & 47 \\
\hline rempong & 21 & 49 \\
\hline
\end{tabular}

\section{Pemaknaan Sesuai dengan KBBI}

Dari sepuluh kata yang menjadi bahan pemaknaan oleh pengguna bahasa Indonesia, terdapat tiga kata yang sebagian besar dimaknai benar atau sesuai dengan KBBI (2013). Katakata tersebut adalah absen, absensi, dan kosong. Pemaknaan kata-kata tersebut dijelaskan berikut ini. 
Dari 70 responden, 55 responden di antaranya memaknai kata absen dengan benar atau sesuai dengan KBBI. Kata tersebut dimaknai dengan arti tidak hadir. Hal itu terlihat dari pilihan responden pada kalimat Anak itu selalu saja absen dalam pelajaran matematika sehingga nilainya rendah dalam angket. Kemudian, untuk kata absensi, 43 responden memaknainya dengan benar, yaitu dengan arti ketidakhadiran. Hal itu terlihat pada pilihan mereka pada kalimat Absensi pegawai perusahaan Podomoro menurun dan mencapai 5\% di tahun 2016. Untuk kata kosong, 50 responden memaknainya dengan benar, yaitu dengan arti hampa atau tidak ada. Hal itu terlihat dari pilihan mereka pada kalimat Keadaan hatinya kosong selepas kehilangan adiknya.

Sebagian besar responden telah mamaknai tiga kata tersebut dengan benar. Pemaknaan kata absen, absensi, dan kosong sudah sesuai atau sejalan dengan makna dalam KBBI. Absen dalam KBBI (2013) bermakna tidak hadir, absensi bermakna ketidakhadiran, dan kosong bermakna hampa atau tidak ada. Khusus pada kata kosong, tidak dapat lagi dipadankan dengan kata nol karena kedua kata tersebut merujuk pada dua hal yang berbeda. Kosong merujuk pada sifat dan nol merujuk pada angka.

Walaupun ketiga kata tersebut telah dimaknai dengan benar oleh sebagian besar responden, tetapi hasil tersebut masih disayangkan karena dari sepuluh kata tersebut, hanya ada tiga kata yang dimaknai sesuai dengan KBBI. Padahal, peran kamus sangat penting dalam memaknai sebuah kata, tidak hanya bagi masyarakat Indonesia, tetapi juga bagi pembelajar BIPA (Purwiyanti, dkk, 2017: 174). Apalagi sepuluh kata tersebut sudah berwujud istilah tertentu yang memiliki makna pasti meskipun tanpa konteks kalimat. Hal itu sejalan dengan pandangan Rosyidi (2011: 80) dalam penelitiannya yang mengemukakan bahwa makna istilah tetap harus merujuk pada kamus karena maknanya sudah jelas dan hal itu sangat membantu dalam penerjemahan kata tersebut ke bentuk bahasa lainnya.

\section{Pemaknaan Tidak Sesuai dengan KBBI}

Dari sepuluh kata yang menjadi bahan pemaknaan oleh pengguna bahasa Indonesia, terdapat tujuh kata yang sebagian besar dimaknai salah atau tidak sesuai dengan KBBI. Katakata tersebut adalah acuh, bergeming, nuansa, seronok, carut-marut, notulen, dan rempong. Pemaknaan kata-kata tersebut dijelaskan berikut ini.

Dari 70 responden, 39 responden di antaranya memaknai kata acuh secara salah. Kata tersebut dimaknai dengan arti tidak peduli. Hal itu terlihat pada pilihan mereka dalam kalimat Kehadirannya selalu diacuhkan dan diabaikan oleh ayahnya sendiri yang terdapat dalam 
angket, sedangkan 31 responden di antaranya memaknai kata acuh dengan arti peduli, sebagaimana pilihan mereka pada kalimat Sebagai tanda cintanya, Zulham senantiasa mengacuhkan istrinya.

Dilihat dari konteks kedua kalimat tersebut, sangat jelas tergambar makna kata acuh pada masing-masing kalimat. Dengan melihat konteks tersebut, para responden, sebagian besar, memaknainya secara salah. Dalam KBBI (2013) makna acuh adalah peduli. Tidak mengherankan jika para responden memaknai acuh secara keliru karena pemahaman mendasar sebagian masyarakat tersebut sering ditemukan dalam media massa, baik cetak maupun elektronik yang memaknai kata acuh dengan arti tidak peduli. Pemahaman inilah yang diikuti oleh sebagian masyarakat dan membuat mereka salah kaprah.

Selanjutnya, dari 70 responden, 53 responden di antaranya memaknai kata bergeming dengan arti bergerak, sebagaimana yang terlihat pada pilihan mereka dalam kalimat Messi diam tak bergeming ketika melihat aksi Cristiano Ronaldo. Kemudian, 17 responden memaknai kata bergeming dengan arti diam, sebagaimana yang terlihat dalam pilihan mereka pada kalimat Buffon selalu saja bergeming dan membatu ketika menerima bola sepakan Cristiano Ronaldo.

Dilihat dari konteks kedua kalimat tersebut, sangat jelas tergambar makna kata bergeming pada masing-masing kalimat. Dengan melihat konteks tersebut, para responden, sebagian besar memaknai salah kata bergeming. Sebagian besar atau 53 responden selalu memasangkan kata tidak dengan kata bergeming. Padahal, jika rujukan makna yang dimaksud adalah diam, kata tidak sebelum kata bergeming tidak perlu ada. Bahkan, jika kata tidak ditambahkan sebelum kata bergeming, kata tidak dapat merusak dan mengaburkan makna kata bergeming itu sendiri. Dalam KBBI (2013) makna kata bergeming adalah diam.

Selanjutnya, sebanyak 39 responden dari 70 responden memaknai kata nuansa dengan arti suasana. Hal itu tergambar pada pilihan mereka dalam kalimat Nuansa teror sangat terasa di Paris selepas peledakan bom oleh teroris. Selebihnya, yaitu 31 responden memaknai kata nuansa dengan arti perbedaan atau variasi. Hal itu terlihat pada pilihan mereka dalam kalimat Warna merah marun dan merah bata memiliki nuansa yang kecil yang terdapat pada angket.

Dilihat dari konteks kedua kalimat tersebut, sangat jelas tergambar makna kata nuansa pada masing-masing kalimat. Dengan melihat konteks tersebut, para responden sebagian besar memaknai salah kata nuansa. Responden selalu memadankan kata nuansa dengan suasana. Padahal, keduanya memiliki makna yang berbeda. Nuansa dalam KBBI (2013) bermakna perbedaan atau variasi, sementara suasana bermakna keadaan atau hawa. 
Selanjutnya, kata seronok, carut-marut, notulen, dan rempong juga sebagian besar dimaknai salah oleh para responden, yaitu dimaknai dengan arti tidak senonoh oleh 43 responden, kekacauan atau tidak keruan oleh 52 responden, petugas pencatat hasil rapat atau diskusi oleh 47 responden, dan ribet atau ikut campur urusan orang lain oleh 49 responden. Pemaknaan itu tergambar dari pilihan mereka pada kalimat berikut. (1) Aksi seronok yang dilakukan Ariel dan Luna Maya tidak patut untuk ditiru. (2) Presiden Joko Widodo mengambil keputusan tegas dalam menghadapi carut-marut perpolitikan Indonesia. (3) Dalam setiap diskusi, seorang moderator selalu didampingi oleh seorang notulen. (4) Di dunia ini, banyak perempuan rempong yang suka mengurusi urusan orang lain.

Dilihat dari konteks kalimat-kalimat tersebut, sangat jelas tergambar makna kata-kata tersebut dan sebagian besar responden memaknainya secara salah. Semua makna yang dipilih oleh sebagian besar responden tidak sejalan dengan makna dalam KBBI. Dalam KBBI, kata seronok bermakna menyenangkan hati atau sedap dilihat. Kata carut-marut bermakna bermacam-macam perkataan keji atau segala jenis bekas goresan. Kata notulen bermakna catatan singkat hasil rapat. Kata rempong bermakna terikat kakinya.

Khusus untuk kata notulen dan rempong, yang merupakan bentuk tidak baku dari notula dan rimpung, dimaknai dengan arti yang tidak bersumber pada bentuk bakunya. Kata notulen dengan bentuk baku notula dalam KBBI (2013) bermakna catatan hasil rapat. Sementara itu, rempong dengan bentuk baku rimpung dalam KBBI (2013) bermakna terikat kakinya.

Selanjutnya, dari hasil penelitian diperoleh beberapa alasan responden dalam memberikan pemaknaan. Alasan-alasan tersebut dirangkum dalam tabel berikut.

Tabel 3

Alasan Pemaknaan Kata

\begin{tabular}{lc}
\hline \multicolumn{1}{c}{ Alasan Pemaknaan } & Frekuensi \\
\hline Melihat pada media massa & 28 \\
\hline Mendengar dari orang lain (masyarakat) & 17 \\
\hline Menjadi kebiasaan & 11 \\
\hline Melihat makna dalam KBBI & 14 \\
\hline
\end{tabular}

Berdasarkan tabel tersebut, terdapat empat alasan utama para responden dalam memberikan pemaknaan, yaitu melihat pada media massa, sering mendengar dari orang lain (masyarakat), menjadi kebiasaan sehari-hari, dan melihat makna pada KBBI. Penjelasan lebih lanjut mengenai penyebab-penyebab tersebut dipaparkan berikut ini. 


\section{a. Melihat pada Media Massa (Cetak maupun Elektronik)}

Penyebab pertama pemaknaan yang hadir adalah sering melihat pada media massa, baik cetak maupun elektronik. Dari 70 responden, 28 responden di antaranya menyatakan alasan ini. Mereka menyatakan bahwa media pasti menggunakan kata dengan makna yang benar dan sesuai dengan makna dalam kamus, sehingga mereka tidak perlu lagi mengeceknya dalam kamus. Padahal, nyatanya terdapat beberapa media yang sering menggunakan kata dengan makna yang keliru. Ini banyak terjadi pada portal-portal berita daring, seperti pada portal berita detiknews.com edisi 26 Agustus 2016.

Dalam portal tersebut terdapat sebuah berita dengan judul "Menpan: Banyak PNS Datang ke Kantor Hanya untuk Absen Saja, Bukan Kerja”. Isi berita tersebut menggambarkan bahwa banyak PNS yang datang ke kantor hanya untuk menyetor atau mengisi daftar kehadiran dan tidak bekerja. Dari isi berita tersebut disimpulkan bahwa makna absen adalah mengisi daftar hadir. Makna tersebut tidak sejalan dengan makna dalam KBBI (2013), yaitu tidak hadir.

Selain itu, ada juga dalam portal berita kompas.com edisi 15 September 2015. Dalam portal tersebut terdapat berita dengan judul "Sri Mulyani dan Carut-Marut Pajak Penulis". Isi berita tersebut tentang Menteri Keuangan, Sri Mulyani yang dibuat pusing mengenai pajak penulis. Para penulis meminta Sri Mulyani untuk meninjau ulang besaran Norma Penghitungan Penghasilan Netto (NPPN) pajak penulis karena besaran NPPN penulis sangat berpengaruh kepada pendapatan para penulis. Jika memperhatikan konteks tersebut, maka makna carut-marut dalam judul berita itu adalah tidak keruan. Makna tersebut tidak sesuai dengan makna dalam KBBI (2013). Dalam KBBI (2013) carut-marut bermakna segala jenis perkataan keji. Jika yang dimaksud dalam berita tersebut tidak keruan, seharusnya digunakan kata karut-marut.

\section{b. Sering Mendengar dari Orang Lain (Masyarakat)}

Dari 70 responden, 17 responden di antaranya menyatakan bahwa alasan mereka memberikan pemaknaan karena sering mendengar masyarakat menggunakannya, baik dalam obrolan maupun dalam tulisan. Mereka mengungkapkan bahwa makna kata yang sering digunakan oleh masyarakat umum sudah pasti merupakan makna yang benar karena masyarakat telah menerima makna tersebut. Padahal, tidak semua kata yang digunakan oleh masyarakat mengandung makna yang benar atau sesuai dengan makna dalam kamus, khususnya pada makna istilah. Jika hal itu dibiarkan, tentu berujung pada salah kaprah dan dapat mengakibatkan pergeseran atau perubahan makna pada kata. 


\section{c. Menjadi Kebiasaan}

Penyebab ketiga hadirnya pemaknaan yang dilakukan oleh para responden adalah telah menjadi kebiasaan mereka. Dari 70 responden, 11 responden di antaranya menyatakan telah terbiasa memaknai kata-kata bahasa Indonesia sesuai dengan pemahaman mereka. Penyebab ketiga ini berhubungan erat dengan penyebab pertama dan kedua. Setelah menjadi kebiasaan, pemaknaan yang dilakukan pun sangat sulit berubah mengikuti pemaknaan yang benar sesuai dengan makna dalam kamus. Diperlukan pengubahan pola pikir kepada para responden agar lebih memaknai kata sesuai dengan makna dalam kamus, khususnya istilah-istilah yang telah memiliki makna yang jelas.

\section{d. Melihat Makna dalam Kamus Besar Bahasa Indonesia (KBBI)}

Dari 70 responden, 14 responden di antaranya memaknai kata dengan melihat atau menyesuaikan makna pada KBBI. Dengan kata lain KBBI dijadikan dasar untuk memaknai kata. Responden yang mengungkapkan alasan ini adalah responden yang berasal dari kalangan mahasiswa, khususnya mahasiswa jurusan bahasa Indonesia.

Dengan melihat hasil tersebut, penelitian ini memperoleh fakta bahwa sebagian besar responden masih menggunakan makna yang salah kaprah. Jika hal itu dibiarkan, maka pergeseran atau perubahan makna dapat terjadi. Hal itu pun semakin membuat bahasa Indonesia kacau, seperti yang diungkapkan oleh Sartini (2014: 208). Dengan kacaunya bahasa Indonesia, dapat memengaruhi eksistensi dan penghargaan terhadap bahasa Indonesia.

Selain itu, para responden mengungkapkan bahwa alasan pemaknaan sebagian besar berasal dari kebiasaan melihat pada media massa. Mereka mengungkapkan bahwa media massa sudah pasti menggunakan kata dengan makna yang benar. Oleh karena itu, mereka cenderung mengikuti makna yang dipahami oleh media massa. Padahal, tidak semua media massa menggunakan kata dengan makna yang benar. Ramadan (2017) dalam penelitiannya menemukan bahwa media massa daring banyak menggunakan kata dengan makna yang salah atau tidak sesuai dengan KBBI. Hal itu ditemukan dalam kata acuh, bergeming, absen, nuansa, absensi, dan carut-marut.

Kemudian, pemaknaan berdasarkan KBBI hanya dilakukan oleh sebagian kecil responden. Ini menunjukkan bahwa penggunaan KBBI sebagai referensi pemaknaan kata masih kecil. Padahal, KBBI merupakan referensi pertama dalam berbahasa Indonesia yang baik dan benar. KBBI setingkat dengan kedudukan Oxford dictionary ketika berbahasa Inggris. Fakta ini sejalan dengan penelitian Sulastri (2016) yang menemukan bahwa penggunaan atau pemanfaatan KBBI 
oleh pengajar masih rendah. Untuk itu, diperlukan berbagai upaya untuk mengembalikan eksistensi penggunaan bahasa Indonesia yang baik dan benar.

\section{Upaya Memperbaiki Penyalahkaprahan Makna}

Penyalahkaprahan yang terjadi pada penelitian ini dapat diperbaiki dengan beberapa upaya. Pertama, berdasarkan hasil penelitian bahwa sebagian besar responden mengikuti makna dari media massa dan banyak dari media massa yang menggunakan makna yang salah, maka diwajibkan kepada redaktur dan seluruh komponen media massa untuk menggunakan kata dengan makna yang sesuai dengan KBBI, khususnya pada istilah yang memiliki makna jelas. Hal itu dilakukan agar pembaca dan pendengar dapat memahami berita dan dapat pula memahami makna dari kata-kata penyusun berita itu dengan benar.

Kedua, penelitian ini memotret persepsi pengguna bahasa Indonesia yang berasal dari kalangan yang berpendidikan menengah ke atas dan hasilnya sebagian besar dari mereka salah dalam memaknai kata. Maka dari itu, diharuskan dalam pembelajaran, kualitas bahasa para pendidik (guru dan dosen) tinggi. Hal itu disebabkan di tangan merekalah proses pendidikan formal dimulai dan dari merekalah lahir kemampuan-kemampuan para peserta didik, yang salah satunya adalah bahasa. Subagyo (2011: 12) mengungkapkan bahwa pendidik menjadi men and women behind the gun yang menentukan keberhasilan pembelajaran bahasa, baik di tingkat dasar, menengah, maupun di tingkat tinggi. Jadi, guru dan dosen diwajibkan menggunakan katakata dengan makna yang benar dalam pembelajaran. Hal itu juga berguna untuk mempertahankan eksistensi bahasa Indonesia (Arifin, 2015: 85).

Ketiga, menumbuhkan sikap positif terhadap bahasa Indonesia. Berdasarkan hasil wawancara dengan Dr. Yetti Mulyati, dosen ahli kebahasaan Universitas Pendidikan Indonesia, beliau menyatakan bahwa menumbuhkan sikap positif terhadap bahasa Indonesia harus dilakukan dan ditingkatkan, baik melalui penyosialisasian bahasa Indonesia yang benar di seminar, kuliah umum, maupun ketika berbincang-bincang dengan teman. Tidak perlu lagi merasa minder mendengar ejekan teman ketika menegur teman tersebut karena menggunakan bahasa Indonesia yang salah. Penutur harus percaya diri demi tetap menjaga eksistensi bahasa Indonesia yang benar.

Selain itu, sikap positif juga dapat dilakukan dengan senantiasa menggunakan KBBI sebagai dasar atau referensi dalam berbahasa Indonesia. Tidak perlu lagi merasa sulit melihat KBBI yang bentuknya besar dan berat karena saat ini telah disediakan format KBBI yang berbentuk mobile aplication dan dapat diunduh secara gratis di masing-masing smartphone 
masyarakat. Disediakan pula KBBI daring sehingga dapat diakses kapan saja dan di mana saja melalui smartphone.

Keempat, membuat aturan yang mengikat mengenai penggunaan bahasa Indonesia yang baik dan benar. Beliau menambahkan bahwa diperlukan aturan yang mengikat bagi pengguna bahasa Indonesia agar tetap menggunakan bahasa Indonesia sesuai dengan koridor atau kaidah yang berlaku. Aturan tersebut dapat berupa pemberian sanksi bagi pengguna bahasa Indonesia jika tidak menggunakan bahasa Indonesia yang baik dan benar, khususnya di ruang publik. Selain itu, dapat pula dibuat aturan berupa penetapan UKBI (Uji Kemahiran Berbahasa Indonesia) sebagai syarat bagi masyarakat yang ingin menduduki kursi pemerintahan, menjadi pendidik, menjalankan media massa, atau menjadi petinggi lainnya. Sangat wajar ketika menetapkan aturan seperti itu karena aparat pemerintahan, pendidik, pembuat media massa, dan petinggi lainnya sangat diperhatikan oleh masyarakat umum, bahkan tidak sedikit yang ditiru oleh masyarakat.

\section{PENUTUP}

Penyalahkaprahan makna oleh pengguna bahasa Indonesia, berdasarkan hasil penelitian, berada pada kategori tinggi-dalam artian sebagian besar responden masih menggunakan makna yang salah kaprah terhadap kata dalam bahasa Indonesia. Dari 10 kata yang diujicobakan, terdapat 7 kata yang disalahkaprahkan maknanya. Kata-kata tersebut adalah acuh, bergeming, nuansa, seronok, carut-marut, notulen, dan rempong. Masing-masing kata tersebut dimaknai tidak peduli, bergerak, suasana, tidak baik atau tidak patut, tidak keruan, petugas pencatat hasil rapat, dan senang mencampuri urusan atau ribet. Padahal, dalam KBBI (2013) masing-masing kata tersebut bermakna peduli, diam, variasi, sedap dilihat, berbagai perkataan keji atau bekas goresan, catatan hasil rapat, dan terikat kakinya.

Kemudian, hanya ada 3 kata yang dimaknai secara tepat atau sesuai dengan makna dalam KBBI (2013). Kata-kata tersebut adalah absen, absensi, dan kosong. Masing-masing kata tersebut telah dimaknai sesuai dengan makna dalam KBBI (2013), yaitu tidak hadir, ketidakhadiran, dan hampa atau tidak ada.

Pemaknaan atas kata-kata tersebut disebabkan oleh beberapa alasan, antara lain: (a) melihat dan mendengar dari media massa, (b) mendengar dari orang lain (masyarakat), (c) menjadi kebiasaan sehari-hari, dan (d) melihat makna dalam KBBI. Di antara ke empat alasan tersebut, alasan melihat pada media massa menjadi alasan terbesar. Dari 70 respoden, 28 responden di antaranya menggunakan alasan itu. Berbanding terbalik dengan alasan melihat pada 
KBBI. Alasan tersebut hanya digunakan oleh 14 responden. Dengan demikian, diperlukan upaya untuk menyadarkan pengguna bahasa Indonesia tentang pentingnya menggunakan KBBI dalam berbahasa Indonesia yang baik dan benar.

Ada pun beberapa upaya yang dapat dilakukan untuk meminimalkan atau memperbaiki penyalahkaprahan makna kata tersebut, antara lain (a) mewajibkan redaktur dan seluruh komponen media massa untuk menggunakan kata dengan makna yang sesuai dengan KBBI, khususnya pada istilah yang memiliki makna jelas; (b) meningkatkan kualitas bahasa Indonesia para pendidik; (c) menumbuhkan sikap positif terhadap bahasa Indonesia; dan (d) menetapkan aturan yang mengikat bagi pengguna bahasa Indonesia agar menggunakan bahasa Indonesia yang baik dan benar, baik melalui pemberian sanksi maupun penetapan UKBI sebagai standar pengakuan kemampuan berbahasa Indonesia.

\section{DAFTAR PUSTAKA}

Arifin, M. (2015). Mempertahankan Bahasa Indonesia sebagai Jati Diri Bangsa. Prosiding Seminar Nasional Bulan Bahasa UNIB, 82-87. Bengkulu: FKIB UNIB.

Aslinda \& Syafyahya, L. (2010). Pengantar Sosiolinguistik. Bandung: Refika Aditama.

Chaer, A \& Leonie, A. (2010). Sosiolinguistik Perkenalan Awal. Jakarta: Rineka Cipta.

Departemen Pendidikan Nasional. (2013). Kamus Besar Bahasa Indonesia Edisi Keempat. Jakarta: Gramedia Pustaka Utama.

I., Jeniarti. (2019). Kosakata Serapan Bahasa Jepang dalam KBBI: Analisis Struktur dan Makna. Ranah: Jurnal Kajian Bahasa, 8(1), 77-91. https://doi.org/10.26499/rnh.v8i1.938

Kementerian Pendidikan dan Kebudayaan Republik Indonesia. (2016). KBBI Daring. [Online]. Diakses dari https://kbbi.kemdikbud.go.id/Cari/Index

Kridalaksana, H. (1985). Sikap dan Fungsi Bahasa. Flores: Nusa Indah.

Mahsun. (2005). Metode Penelitian Bahasa: Tahapan, Strategi, Metode, dan Tekniknya. Jakarta: Raja Grafindo.

Marsudi, \& Zahrok, S. (2015). Kesetiaan Berbahasa Indonesia Dipertanyakan di Era Globalisasi. Jurnal Sosial Humaniora, 8(1), 95-105. https://doi.org/10.12962/j24433527.v8i1.1245

Miles, M. B., \& Huberman A. M. (1992). Analisis Data Kualitatif. Terjemahan Tjetjep Rohendi Rohidi. Jakarta: Penerbit Universitas Indonesia.

Moleong, L. J. (2005). Metode Penelitian Kualitatif (Revisi). Bandung: Remaja Rosdakarya.

Parera, J. (2004). Teori Semantik. Jakarta: Erlangga.

Purwiyanti, Y, dkk. (2017). Strategi Komunikasi Pemelajar Bahasa Indonesia bagi Penutur Asing (BIPA) Asal Filipina. Ranah: Jurnal Kajian Bahasa, 6(2), 160-179. https://doi.org/10.26499/rnh.v6i2.448

Rahayu, A. P. (2015). Menumbuhkan Bahasa Indonesia yang Baik dan Benar dalam Pendidikan dan Pengajaran. Jurnal Paradigma, 2(1), 15-20. http://ejournal.kopertais4.or.id/mataraman/index.php/paradigma/article/view/886 
Ramadan, S. (2017). Salah Kaprah Pemaknaan Kata dalam Bahasa Indonesia dan Upaya Perbaikannya (Studi Kasus pada Media Massa Berbasis Daring). Prosiding Seminar Internasional Riksa Bahasa XI UPI, 404-409. Bandung: Prodi PBI SPS UPI.

Rosidi, A. (2010). Bus, Bis, Bas, Berbagai Masalah Bahasa Indonesia. Jakarta: Pustaka Jaya.

Rosyidi, A. W. (2011). Peran Makna dalam Penerjemahan. LiNGUA: Jurnal Ilmu Bahasa dan Sastra, 2(1), 70-85. https://doi.org/10.18860/ling.v2i1.559

Sari, B. P. (2015). Dampak Penggunaan Bahasa Gaul di Kalangan Remaja terhadap Bahasa Indonesia. Prosiding Nasional Bahasa dan Sastra Indonesia. Malang: Universitas Muhammadiyah Malang. $\quad$ http://research-report.umm.ac.id/index.php/SENASBASA/article/view/2232

Sartini, N. W. (2014). Revitalisasi Bahasa Indonesia dalam Konteks Kebahasaan. Masyarakat, Kebudayaan dan Politik, 27(4), 206-210. https://doi.org/10.20473/mkp.V27I42014.196-200

Setyadi, A. (2015). Pemakaian Kompetitif: Macam Bidang dan Penyebab. Humanika, 20(2), 74-81.https://doi.org/10.14710/humanika.20.2.74-81

Subagyo, P. A. (2011). Perkuliahan Bahasa Indonesia di Tengah Arus Global. In S. Wijayanti \& Yulianeta (Eds.), Bahasa dan Sastra Indonesia di Tengah Arus Global (pp. 3-12). Bandung: Jurusan Pendidikan Bahasa dan Sastra Indonesia FPBS UPI.

Sulastri, H. (2016). Keberterimaan dan Keterpakaian Kamus Besar Bahasa Indonesia bagi Pengajar. Prosiding Seminar Hasil Penelian Kebahasaan Dan Kesastraan. Yogyakarta: Balai Bahasa Daerah istimewa Yogyakarta.

Sumarsono (Ed.). (2012). Pengantar Semantik. Yogyakarta: Pustaka Pelajar.

Susanti, D. I. (2015). Peranan Bahasa Indonesia di Tengah Maraknya Penggunaan Bahasa Asing. Deiksis, 3(4), 365-378. http://dx.doi.org/10.30998/deiksis.v3i04.441 